\title{
Comparative analysis of corrosion resistance of Zinc and Zn-Al-Mg coatings on
}

\section{carbon steel}

\author{
Análise comparativa da resistência à corrosão de revestimentos de Zinco e Zn-Al-Mg em aço \\ carbono
}

Análisis comparativo de la resistencia a la corrosión de recubrimientos de zinc y Zn-Al-Mg sobre acero al carbono

\author{
Alberto Nei Carvalho Costa \\ ORCID: https://orcid.org/0000-0002-7302-1625 \\ São Paulo State University, Brazil \\ E-mail: alberto.nei@unesp.br \\ Gilmar Clemente Silva \\ ORCID: https://orcid.org/0000-0003-2348-6173 \\ Fluminense Federal University, Brazil \\ E-mail: gilmarcs@id.uff.br \\ Elivelton Alves Ferreira \\ ORCID: https://orcid.org/0000-0001-6991-6568 \\ Fluminense Federal University, Brazil \\ E-mail: eliveltonalves@id.uff.br \\ Roberto Zenhei Nakazato \\ ORCID: https://orcid.org/0000-0001-7897-1905 \\ São Paulo State University, Brazil \\ E-mail: roberto.zenhei@unesp.br
}

\begin{abstract}
One of the main ways to protect steel against corrosion is by the galvanizing process. This process has been continuously developed and its first optimization was performed by the addition of Aluminum in the coating. As a result, $\mathrm{Zn}-5 \mathrm{wt} . \% \mathrm{Al}$ and 55wt.\%Al-Zn coatings were developed. Recently, the search for increased corrosion resistance led to the development of zinc coating with the addition of magnesium and aluminum. In this work, a comparative study of the corrosion resistance of zinc coated steel and $\mathrm{Zn}-2 \mathrm{wt} . \% \mathrm{Al}-1 \mathrm{wt} . \% \mathrm{Mg}$ alloy coated steel was performed. Samples were exposed to immersion corrosion tests in $0.1 \mathrm{M} \mathrm{NaCl}$ electrolyte and were analyzed by using SEM, XDR and EIS. On zinc-coated steel, the steel substrate was attacked after 48 days of immersion, while on Zn$2 \mathrm{wt} . \% \mathrm{Al}-1 \mathrm{wt} . \% \mathrm{Mg}$ coated steel, the steel substrate showed corrosive process after 90-day of immersion. The corrosion product formed from $\mathrm{Zn}-2 \mathrm{wt} . \% \mathrm{Al}-1 \mathrm{wt} . \% \mathrm{Mg}$ coated steel is the main cause of its better corrosion resistance compared to zinc coated steel.
\end{abstract}

Keywords: Coated Steel; Corrosion; Magnesium; Microstructure.

\section{Resumo}

Uma das principais formas de proteger o aço contra a corrosão é pelo processo de galvanização. Este processo tem sido continuamente desenvolvido e sua primeira otimização foi realizada com a adição de Alumínio no revestimento. Como resultado, foram desenvolvidos revestimentos de $\mathrm{Zn}-5 \%$ em peso de $\mathrm{Al}$ e $55 \%$ em peso de $\mathrm{Al}-\mathrm{Zn}$. Recentemente, a busca por maior resistência à corrosão levou ao desenvolvimento do revestimento de zinco com adição de magnésio e alumínio. Neste trabalho, foi realizado um estudo comparativo da resistência à corrosão do aço revestido com zinco e do aço revestido com liga de $\mathrm{Zn}-2 \% \mathrm{Al}-1 \% \mathrm{Mg}$. As amostras foram expostas a testes de corrosão por imersão em eletrólito $\mathrm{NaCl} 0,1 \mathrm{M}$ e analisadas por meio de MEV, XDR e EIS. No aço revestido com zinco, o substrato de aço foi atacado após 48 dias de imersão, enquanto no aço revestido com $\mathrm{Zn}-2 \% \mathrm{Al}-1 \% \mathrm{Mg}$ revestido em peso, o substrato de aço apresentou processo corrosivo após 90 dias de imersão. O produto de corrosão formado a partir de aço revestido de $\mathrm{Zn}-2 \% \mathrm{Al}-1 \%$ em peso de $\mathrm{Mg}$ é a principal causa de sua melhor resistência à corrosão em comparação ao aço revestido de zinco.

Palavras-chave: Aço revestido; Corrosão; Magnésio; Microestrutura.

\section{Resumen}

Una de las principales formas de proteger el acero contra la corrosión es mediante el proceso de galvanizado. Este proceso se ha desarrollado continuamente y su primera optimización se realizó mediante la adición de Aluminio en el 
recubrimiento. Como resultado, se desarrollaron revestimientos de $\mathrm{Zn}-5 \%$ en peso de $\mathrm{Al}$ y $55 \%$ en peso de $\mathrm{Al}-\mathrm{Zn}$. Recientemente, la búsqueda de una mayor resistencia a la corrosión condujo al desarrollo de un revestimiento de zinc con la adición de magnesio y aluminio. En este trabajo, se realizó un estudio comparativo de la resistencia a la corrosión del acero recubierto de zinc y el acero recubierto de aleación de $\mathrm{Zn}-2 \%$ en peso Al-1\% en peso $\mathrm{Mg}$. Las muestras se expusieron a pruebas de corrosión por inmersión en electrolito de $\mathrm{NaCl} 0,1 \mathrm{M}$ y se analizaron utilizando SEM, XDR y EIS. Sobre acero revestido de zinc, el sustrato de acero fue atacado después de 48 días de inmersión, mientras que sobre acero revestido con $\mathrm{Zn}-2 \%$ en peso de $\mathrm{Al}-1 \%$ en peso de $\mathrm{Mg}$, el sustrato de acero mostró un proceso corrosivo después de 90 días de inmersión. El producto de corrosión formado a partir de acero revestido con $\mathrm{Zn}-2 \%$ en peso Al-1\% en peso Mg es la causa principal de su mejor resistencia a la corrosión en comparación con el acero revestido con zinc.

Palabras clave: Acero revestido; Corrosión; Magnesio; Microestructura.

\section{Introduction}

In order to improve corrosion resistance and reduce costs of galvanized steel sheet, great efforts have been invested into optimization of the zinc coating composition by alloying.

The zinc coating provides corrosion protection to steel by cathodic protection. In addition to the galvanic protection, the insoluble zinc corrosion products formed on the surface in atmospheric conditions assure a barrier effect (Yoo et al., 2014). Nevertheless, the composition of those corrosion products depends on the exposure conditions and this protection is not observed in all environments (Volovitch, 2009; Prosek, 2008; Hosking, 2007; Le Bozec, 2013; Salgueiro, 2015). In the last twenty years, a large effort has been made in order to improve the corrosion resistance of zinc coatings without increasing its thickness or resorting to additional corrosion protection such as protective layers. New metallic coatings alloying zinc with aluminum, magnesium or a combination of both elements have been the subject of numerous studies (Schuerz, 2009; Elvins, 2008; Prosek, 2010; Dutta, 2010; Li, 2012; Diler, 2012; Diler, 2014; Duchoslav, 2014; Persson, 2013; Salgueiro,2015; Klemm, 2011; Thébault, 2015; Chen, 2010). Successful examples are coatings alloyed with aluminum, Zn-5\%Al and Zn-55\%Al. Nowadays, the main development activity is focused on $\mathrm{Zn}-\mathrm{Al}-\mathrm{Mg}$ coatings.

There are several studies about the effect of aluminum and magnesium alloys on corrosion resistance (Frankel, 1998; Kairy, 2016; Zander, 2007. Recently, researchers have evaluated the effect of adding magnesium and aluminum on the microstructure of the zinc coating and on the corrosive process (Krieg, 2014; Vimalanandan, 2014).

Prosek et al. (2016) in a recent study concluded that the mass losses of $\mathrm{Zn}-5 \mathrm{Al}$ and $\mathrm{Zn}-3 \mathrm{Al}-2 \mathrm{Mg}$ coatings varied up to 2-times as a function of their microstructure. In most cases, finer structures were more corrosion resistant, but the phase chemical composition apparently also played an important role. Prosek et al. (2016) suggested that zinc alloy with aluminum and magnesium reduced the corrosive process of zinc due to the stabilization of less soluble and more protective corrosion products. The formation of non-protective corrosion products has been reduced for these alloys. So, the better corrosion resistance of these alloys can be attributed to the availability of ions capable of forming protective corrosion products, which act as a physical barrier in the cathodic regions.

Dutta et al. (2010) analyzed the Morphology and properties of hot dip $\mathrm{Zn}-\mathrm{Mg}$ and $\mathrm{Zn}-\mathrm{Mg}-\mathrm{Al}$ alloy coatings on steel sheet. They verified binary and ternary eutectic phase mixtures in the coatings formed in $\mathrm{Zn}-\mathrm{Mg}$ and $\mathrm{Zn}-\mathrm{Mg}-\mathrm{Al}$ baths, respectively. The $\mathrm{MgZn}_{2}$ formation was observed on the top surface and through the cross-section of the coating carried out in higher $\mathrm{Mg}$ bath. Steels coated in $\mathrm{Zn}-0.5 \% \mathrm{Mg}-0.25 \% \mathrm{Al}$ showed better corrosion resistance than steels coated in pure zinc and $\mathrm{Zn}-\mathrm{Mg}$.

Other authors have also demonstrated a corrosion resistance improvement of coatings based on zinc alloyed with magnesium by comparison to zinc coatings in atmospheric conditions.

In atmospheric conditions in the presence of chlorides, Hosking et al. (2007) attributed to $\mathrm{Mg}$ the ability to facilitate the formation of the protective simonkolleite layer $\left(\mathrm{Zn}_{5}(\mathrm{OH})_{8} \mathrm{Cl}_{2} \cdot \mathrm{H}_{2} \mathrm{O}\right)$. For their part, Volovitch et al. (2009) proved that 
magnesium is also able to avoid the transformation of the protective simonkolleite layer into a mixed layer of smithsonite $\left(\mathrm{ZnCO}_{3}\right)$, hydrozincite $\left(\mathrm{Zn}_{5}\left(\mathrm{CO}_{3}\right)_{2}(\mathrm{OH})_{6}\right)$ and zincite $(\mathrm{ZnO})$. Based on these studies, in atmospheric conditions and in presence of chlorides the corrosion reactions of $\mathrm{Zn}-\mathrm{Mg}$ alloys involve the formation of simonkolleite which preserves the surface by opposition with other corrosion products of zinc. On the order hand, simonkolleite was not detected in corrosion products when the alloy is exposed to climatic conditions with and without contamination by chloride ions (Prosek, 2008; Diler, 2014), or during the early stages in atmospheric corrosion (Thébault, 2015; Chen, 2010).

Hosking et al. (2007) showed in his studies a 3 -fold increase in time to red rust appearance of zinc-magnesium coated steel in a cyclic corrosion test compared to conventional zinc coatings. They attributed the prolonged life time of $\mathrm{ZnMg}$ coatings to the ability of magnesium corrosion products to neutralize hydroxide ions at cathodes creating conditions for insoluble simonkolleite to extend over the corroding surface, retarding thereby the overall corrosion reaction.

Yao et al. (2016) investigated the effect of $\mathrm{Mg}$ content on microstructure and corrosion of $\mathrm{Zn}-\mathrm{Al}-\mathrm{Mg}$ coatings. They attribute that the good corrosion resistance of ZAM coating comes from the flocculent type simonkolleite. The structure of simonkolleite prolongs the micro-path and impedes the movement of $\mathrm{O}_{2}$ and $\mathrm{H}_{2} \mathrm{O}$, ultimately retarding the overall corrosion process of ZAM coating.

Rodriguez et al. (2016) studied the effect of the electrolyte $\mathrm{pH}$ on the corrosion mechanisms of $\mathrm{Zn}-\mathrm{Mg}$ coated steel. The authors suggest that the initial value of the $\mathrm{pH}$ is a critical parameter in the corrosion mechanism. If the $\mathrm{pH}$ is higher than 11 at the beginning of immersion, the surface is passivated and stable with time. The passive layer is composed of hydrozincite $\mathrm{Zn}_{5}\left(\mathrm{CO}_{3}\right)_{2}(\mathrm{OH})_{6}$ and magnesium carbonates $\left(\mathrm{MgCO}_{3}\right.$ and $\left.\mathrm{Mg}_{5}\left(\mathrm{CO}_{3}\right)_{4}(\mathrm{OH})_{2}\right)$. The formation of zincite is inhibited. The presence of chloride ions does not hinder the formation of a protective layer.

In other study, Schurz et al. (2010) found that Zinc-aluminum-magnesium coated steel offers a decisively enhanced corrosion resistance in salt spray test compared to conventional zinc coated steel. Even after short exposure times the entire metallic ZM coating is transformed into a stable, adherent aluminum-rich protecting layer identified as zinc aluminum carbonate hydroxide, $\mathrm{Zn}_{6} \mathrm{Al}_{2}\left(\mathrm{CO}_{3}\right)(\mathrm{OH})_{16 .} 4 \mathrm{H}_{2} \mathrm{O}$. This long-lasting layer protects the steel substrate against corrosive attacks and is the main reason for the enhanced corrosion resistance of the $\mathrm{ZM}$ coating system.

The present work aims to study the effect of $\mathrm{Mg}$ and $\mathrm{Al}$ additions on the morphology and corrosion resistance of the zinc coatings on carbon steel substrate.

\section{Methodology}

\subsection{Materials}

The material for this study was supplied by CSN. Two coatings for steel sheet were investigated: the $\mathrm{Zn}$ coating consisting of $\mathrm{Zn}+0.2 \mathrm{wt} . \% \mathrm{Al}$ and $\mathrm{Zn}-\mathrm{Al}-\mathrm{Mg}$ coating consisting of $\mathrm{Zn}+2 \mathrm{wt} . \% \mathrm{Al}+1 \mathrm{wt} . \% \mathrm{Mg}$. Both materials were produced in a continuous hot-dip galvanizing line. The average coating weight per side was about $135 \mathrm{~g} / \mathrm{m}^{2}$ for conventional $\mathrm{Zn}$ coating and $\mathrm{Zn}-\mathrm{Al}-\mathrm{Mg}$ coating, which corresponds to a coating thickness of $20 \mu \mathrm{m}$. The steel substrate for both coating systems was a low carbon steel.

\subsection{Electrochemical measurements}

$\mathrm{Zn}$ coating and $\mathrm{Zn}$-Al-Mg coating were studied by electrochemical impedance spectroscopy in order to evaluate the corrosion resistance of the coating as a function of immersion time in $0.1 \mathrm{M} \mathrm{NaCl}$ electrolyte at the natural pH. The stability of the open circuit potential (OCP) was previously checked for 20 minutes of immersion. EIS measurements were performed in a frequency range from $100 \mathrm{kHz}$ to $10 \mathrm{mHz}$. All the spectra were recorded at $\mathrm{OCP}$, applying $10 \mathrm{mV}$ sinusoidal perturbation. A 
conventional three-electrode electrochemical cell was used, composed of an $\mathrm{Ag} / \mathrm{AgCl} / \mathrm{KCl}$ saturated reference electrode, a platinum counter-electrode and a working electrode. The sample area in contact with the electrolyte was $0.78 \mathrm{~cm}^{2}$ and the electrolyte volume was $70 \mathrm{ml}$. The cell was placed in a Faraday cage in order to avoid external interferences.

\subsection{SEM and XRD}

The morphology and composition of different phases were evaluated by scanning electron microscopy (SEM), energy dispersive spectroscopy (EDS) and X-ray mapping analysis, both on the top surface and across the cross-section of the coating. Samples of dimension $2 \mathrm{~cm} \times 2 \mathrm{~cm}$ were cut out for X-ray diffraction (XRD) study to detect different phases present in the coating.

After 41, 56 and 90 days of immersion in $0.1 \mathrm{M} \mathrm{NaCl}$ electrolyte at the natural $\mathrm{pH}, \mathrm{Zn}-\mathrm{Al}-\mathrm{Mg}$ coating were cleaned with demineralized water and dried with a dehydrated compressed air system. The metallic surface covered by corrosion products was characterized by scanning electron microscopy (SEM), energy dispersive spectroscopy (EDS) and X-ray diffraction (XRD).

\section{Results and Discussion}

The coating compositions were measured by inductively coupled plasma optical emission spectrometry (ICP-OES) and coating thickness were measured by SEM micrograph. The Table 1 shows the results of properties of the tested coatings.

Table 1. Properties of the tested coatings: Thickness and composition.

\begin{tabular}{|c|c|c|c|c|}
\hline Materials & Thickness $(\mu \mathrm{m})$ & $\mathrm{Al}(\mathrm{wt} \%)$ & $\mathrm{Mg}(\mathrm{wt} \%)$ & $\mathrm{Zn}(\mathrm{wt} \%)$ \\
\hline Zn coating & $20.3 \pm 0.3$ & 0.2 & ---- & 99.8 \\
\hline Zn-Al-Mg coating & $21.1 \pm 0.2$ & 2.1 & 1.2 & 96.7 \\
\hline
\end{tabular}

Source: Authors (2020).

\subsection{Cross section Microstructure before immersion}

Figure 1 shows the cross-sectional images of the $\mathrm{Zn}$ coating and the $\mathrm{Zn}-\mathrm{Al}-\mathrm{Mg}$ coating prior to the $0.1 \mathrm{M} \mathrm{NaCl}$ solution immersion test. Table 2 presents the results of the quantitative analysis performed by EDS in the regions indicated in figure 1 .

$\mathrm{Zn}$ coating has a homogeneous coating consisting of pure zinc and the $\mathrm{Zn}$-Al-Mg coating has a coating formed by of zinc dendrite (phase $\eta$ ) - QT4, ternary eutectic consisting of Mg2Zn11, zinc and aluminum - QT2 and QT3 and small zinc aluminum particles $-\beta$ phase (Prosek et al., 2016). 
Figure 1. Cross-sectional SEM microstructures and EDS analyses for the (A) Zn coating and (B) Zn-Al-Mg coating.

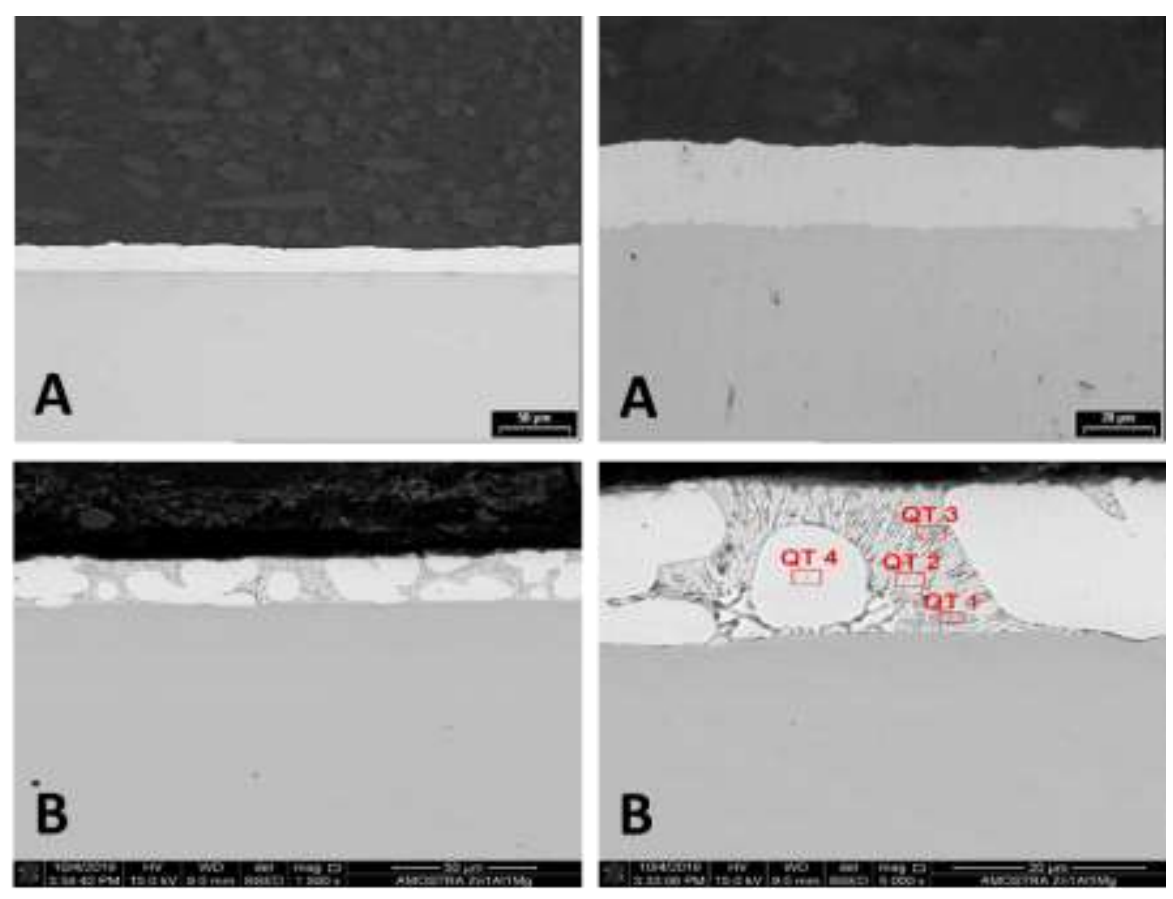

Source: Authors (2020).

Table 2 shows the composition of the regions marked in Figure 1. The results obtained are like the work carried out by Prosek et al. (2016)

Table 2. EDS results of $\mathrm{Zn}-\mathrm{Al}-\mathrm{Mg}$ coating in the Figure 1.

\begin{tabular}{|c|c|c|c|}
\hline & Zn (wt \%) & Al (wt\%) & Mg (wt \%) \\
\hline$\beta$ phase - QT1 & 80.27 & 19.14 & 0.59 \\
\hline Ternary eutectic - QT2 & 91.19 & 6.55 & 2.27 \\
\hline Ternary eutectic - QT3 & 92.54 & 6.74 & 0.72 \\
\hline$\eta$ phase-QT4 & 98.84 & 0.92 & 0.24 \\
\hline
\end{tabular}

Source: Authors (2020).

Figure 2 shows the X-ray diffraction (XRD) analyzes performed on the surfaces of $\mathrm{Zn}$ coating and $\mathrm{Zn}-\mathrm{Al}-\mathrm{Mg}$ coating. It can be observed that in the $\mathrm{Zn}$ coating only the zinc element was detected, while the $\mathrm{Zn}-\mathrm{Al}-\mathrm{Mg}$ coating, besides the $\mathrm{Zn}$ element, was also detected the $\mathrm{Mg}_{2} \mathrm{Zn}_{11}$ compound. 
Figure 2. XRD analyses on Zn coating (ZN) and Zn-Al-Mg coating (ZAM) samples before immersion.

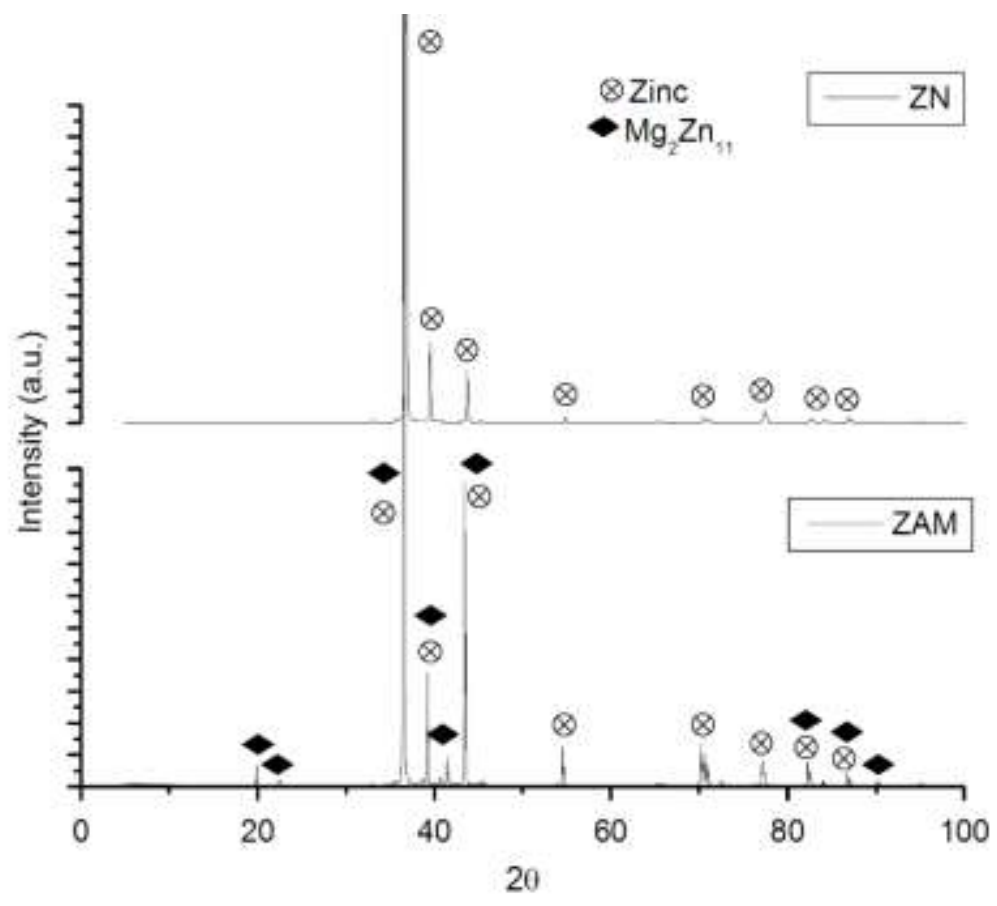

Source: Authors (2020)

\subsection{Cross-section microstructure after immersion}

Figure 3 shows the cross-sectional images of materials $\mathrm{ZN}$ and $\mathrm{Zn}-\mathrm{Al}-\mathrm{Mg}$ after corrosion of the base steel in the total immersion test in $0.1 \mathrm{M} \mathrm{NaCl}$ solution. For $\mathrm{ZN}$ material, corrosion of the base steel occurred after 48 days of immersion, while for $\mathrm{Zn}-\mathrm{Al}-\mathrm{Mg}$ material after 90 days of immersion.

$\mathrm{ZN}$ coating showed uniform corrosive process throughout the zinc coating. For the $\mathrm{Zn}-\mathrm{Al}-\mathrm{Mg}$ coating, it is verified that the corrosive process in the coating was localized, occurring preferentially in the region composed by the ternary eutectic, with the preservation of the zinc dendritic regions. 
Figure 3. Cross-section microestructure and EDS after immersion. (A) $\mathrm{Zn}$ coating - 48 days immersion; (B) $\mathrm{Zn}-\mathrm{Al}-\mathrm{Mg}$ coating -90 days immersion

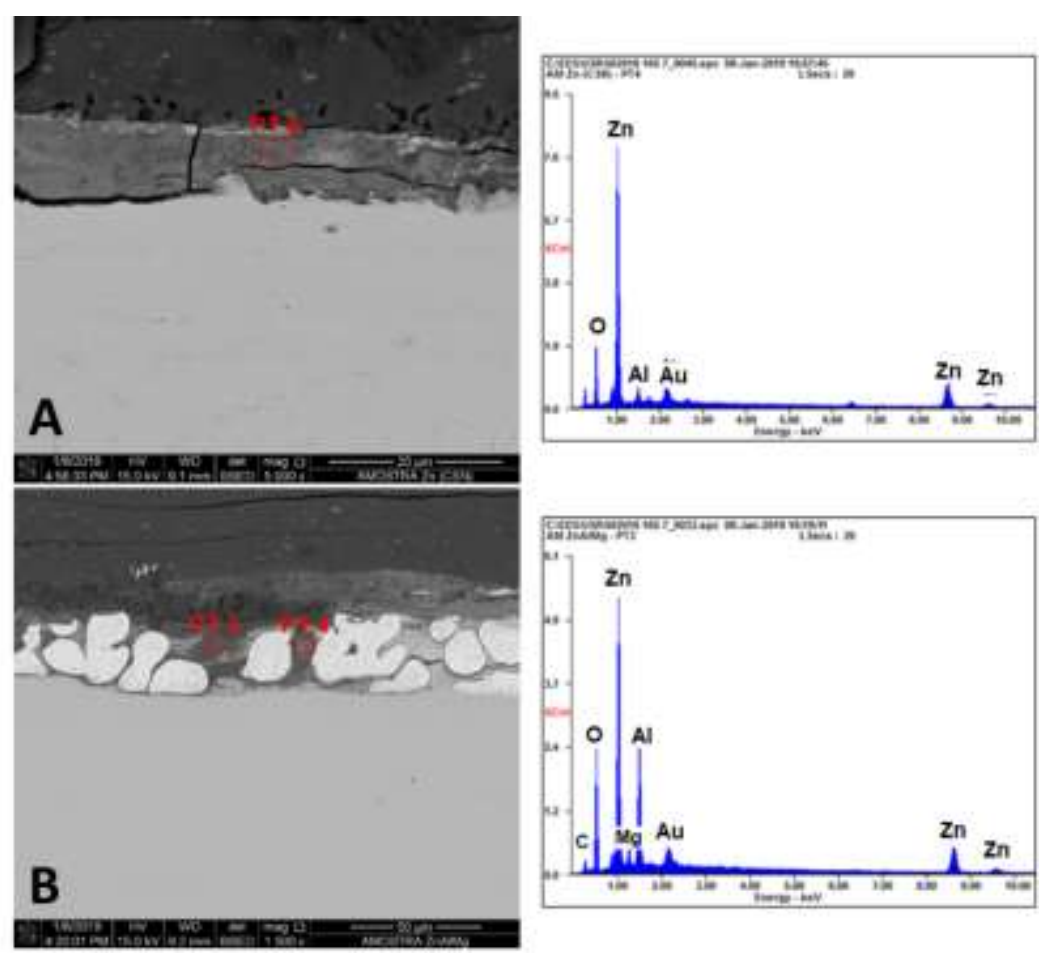

Source: Authors (2020).

Figures 4 and 5 show the X-ray XRD diffraction analyzes on the surface of Zn coating and Zn-Al-Mg coating after immersion in $0.1 \mathrm{M} \mathrm{NaCl}$ solution.

Figure 4. XRD analyses of corrosion products formed on Zn-Al-Mg coating (ZAM). 56 days and 90 days.

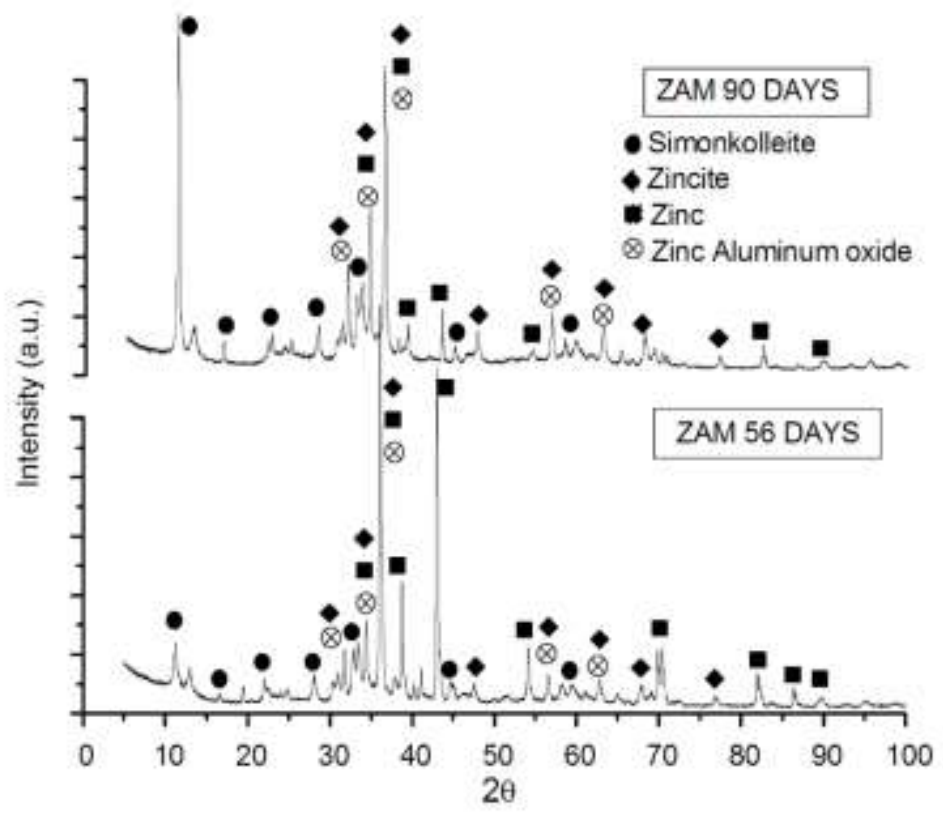


According to Figure 4, the main corrosion products observed on the surface of the $\mathrm{Zn}-\mathrm{Al}-\mathrm{Mg}$ coating were simonkolleite $\left(\mathrm{Zn}_{5}(\mathrm{OH})_{8} \mathrm{Cl}_{2} \mathrm{H}_{2} \mathrm{O}\right)$, Zinc oxide and Zinc-aluminum oxide. Simonkolleite is a compact compound that slows down the corrosive process of the coating.

XRD analysis of the ZN coating in Figure 5, shows that the main corrosion products observed on the material surface are Zinc oxide (zincite) and $\mathrm{Zn}(\mathrm{OH})_{2}$. These corrosion products do not provide effective zinc coating barrier protection.

Figure 5. XRD analyses of corrosion products formed on $\mathrm{ZN}$ coating (ZN). 7 days and 48 days.

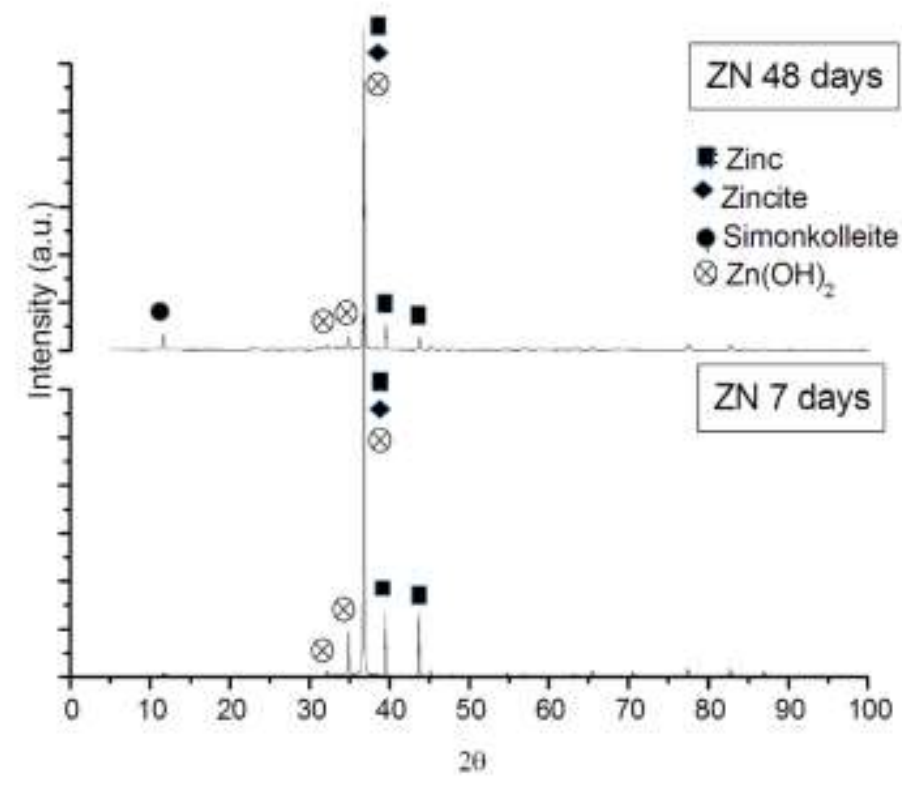

Source: Authors (2020).

\subsection{EIS measurements}

Figure 6 shows the Nyquist diagram of ZN coating and Zn-Al-Mg coating obtained after different immersion times (1 hour, 4 days and 8 days) in $0.1 \mathrm{M} \mathrm{NaCl}$ solution. 
Figure 6. Nyquist diagrams of EIS measurements recorded after 1h, 4 days and 8 days of immersion of $\mathrm{Zn}$ coating (ZN) and $\mathrm{Zn}-\mathrm{Al}-\mathrm{Mg}$ coating (ZAM) in $0.1 \mathrm{M} \mathrm{NaCl}$ at natural $\mathrm{pH}$ (initial $\mathrm{pH} 5.6$ ).

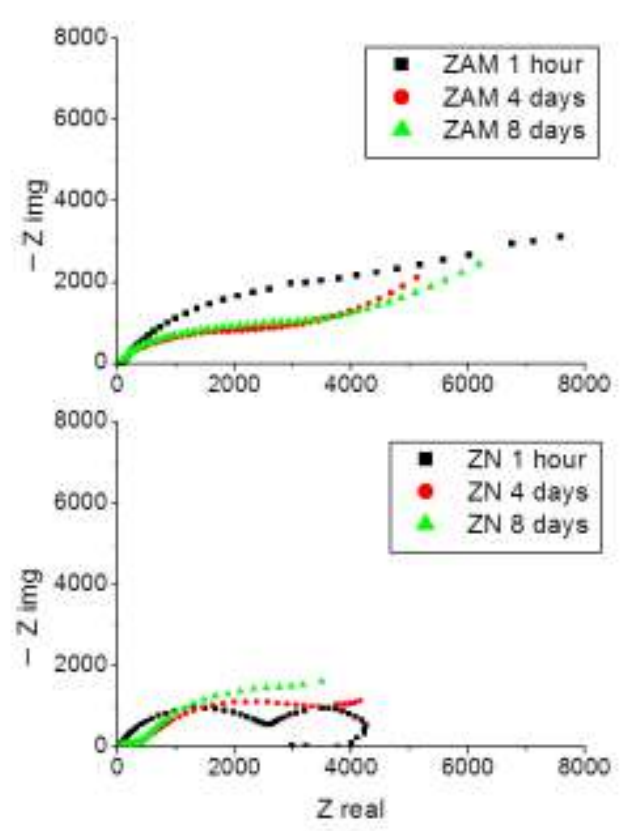

Source: Authors (2020).

For the ZN coating, it can be seen that the Nyquist diagram for 1 hour of immersion presented 2 capacitive arcs, the first arc obtained at high frequencies can be attributed to the formation of a corrosion product film on the surface of the $\mathrm{ZN}$ coating the while the second capacitive arc obtained at medium and low frequency can be attributed to charge transfer resistance of the electric double layer. For longer immersion times ( 4 and 8 days), only the formation of a capacitive arc can be attributed to the corrosion product film formed on the surface of the ZN coating, Yao et al. (2016).

For the $\mathrm{Zn}-\mathrm{Al}-\mathrm{Mg}$ coating, the Nyquist diagram presented only one capacitive arc at high and medium frequencies for all test times. This capacitive arc can also be attributed to the corrosion product film formed on the $\mathrm{Zn}$-Al-Mg coating surface.

The values of the polarization resistance (corrosion product resistance) until the corrosion process of the base steel, are shown in Table 3, indicating that $\mathrm{Zn}-\mathrm{Al}-\mathrm{Mg}$ coating has better corrosion resistance than $\mathrm{ZN}$ coating. ZN coating showed red corrosion with 48 days of immersion in $0.1 \mathrm{M} \mathrm{NaCl}$ solution, while $\mathrm{Zn}-\mathrm{Al}-\mathrm{Mg}$ coating showed only 90 days. 
Table 3. Results of fitting of EIS spectra recorded for $\mathrm{ZN}$ coating and $\mathrm{Zn}-\mathrm{Al}-\mathrm{Mg}$ coating immersed in $0.1 \mathrm{M} \mathrm{NaCl}$ at the natural $\mathrm{pH}$.

\begin{tabular}{|c|c|c|}
\hline & $\mathrm{R}_{\mathrm{pol}} \cdot \mathrm{ZAM}(\Omega)$ & $\mathrm{R}_{\mathrm{pol}} \cdot \mathrm{ZN}(\Omega)$ \\
\hline 1 hour & 6000 & 510 \\
\hline 4 days & 2200 & 290 \\
\hline 8 days & 2500 & 170 \\
\hline 19 days & 3800 & 90 \\
\hline 25 days & 3200 & 50 \\
\hline 48 days & 2700 & ----- \\
\hline 65 days & 2200 & ----- \\
\hline
\end{tabular}

Source: Authors (2020).

\section{Conclusion}

It was concluded that $\mathrm{Zn}-\mathrm{Al}-\mathrm{Mg}$ coating showed higher corrosion resistance than $\mathrm{Zn}$ coating in $0.1 \mathrm{M} \mathrm{NaCl}$ solution immersion test.

The formation of simonkolleite corrosion product on the surface of $\mathrm{Zn}-\mathrm{Al}-\mathrm{Mg}$ coating was responsible for its higher corrosion resistance compared to $\mathrm{Zn}$ coating.

There was no formation of simonkolleite in the zinc coating after immersion in $0.1 \mathrm{M} \mathrm{NaCl}$ solution. Thus, we can attribute that the addition of aluminum and magnesium elements favored the formation of simonkolleite on the surface of the Zn-Al-Mg coating.

\section{Acknowledgments}

This project is supported by the São Paulo State University (UNESP). The authors would like to thank the technical staff in the Research Center of CSN and the Fluminense Federal University (UFF).

\section{References}

Chen, S., Yan, F., Xue, F., Yang, L., \& Liu, J., (2010). X-ray photoelectron spectroscopy investigations of zinc-magnesium alloy coated steel, Materials, Chemistry and Physics, 124, 472-476.

Diler, E., Lescop, B., Rioual, S., Nguyen Vien, G., Thierry, D., \& Rouvellou, B., (2014). Initial formation of corrosion products on pure zinc and MgZn 2 examinated by XPS, Corrosion Science, 79, 83-88.

Diler, E., Rioual, S., Lescop, B., Thierry, D., \& Rouvellou, B., (2012). Chemistry of corrosion products of Zn and MgZn pure phases under atmospheric conditions, Corrosion Science, 65, 178-186.

Duchoslav, J., Arndt, M., Steinberger, R., Keppert, T., Luckeneder, G., Stellnberger, K. H., Hagler, J., Riener, C. K., Angeli, G., \& Stifter, D., (2014). Nanoscopic view on the initial stages of corrosion of hot dip galvanized $\mathrm{Zn}-\mathrm{Mg}-\mathrm{Al}$ coatings, Corrosion Science, 83, $327-334$.

Dutta, M., Halder, A. K., \& Singh, S. B., (2010). Morphology and properties of hot dip Zn-Mg and Zn-Mg-Al alloy coatings on steel sheet, Surface and Coating Technology, 205, 2578-2584. 
Elvins, J., Spittle, J. A., Sullivan, J. H., \& Worsley, D. A., (2008). The effect of magnesium additions on the microstructure and cut edge corrosion resistance of zinc aluminium alloy galvanized steel, Corrosion Science, 50, 1650-1658.

Frankel, G. S., (1998). Pitting corrosion of metals: a review of the critical factors, Journal of the Electrochemical Society, 145, 2186-2198.

Hosking, N. C., Ström, M. A., Shipway, P. H., \& Rudd, C. D., (2007). Corrosion resistance of zinc-magnesium coated steel, Corrosion Science, 49, 36693695 .

Kairy, S. K., Rometsch, P. A., Diao, K., Nie, J. F., Davies, C. H. J., \& Birbilis, N., (2016). Exploring the electrochemistry of 6xxx series aluminum alloys as a function of $\mathrm{Si}$ to $\mathrm{Mg}$ ratio, Cu content, ageing conditions and microstructure, Electrochimica Acta, 190, 92-103.

Klemm, S. O., Schauer, J. C., Schuhmacher, B., \& Hassel, A. W., (2011). High through put electrochemical screening and dissolution monitoring of Mg-Zn material libraries, Electrochimica Acta, 56, 9627-9636.

Krieg, R., Vimalanandan, A., \& Rohwerder, M., (2014). Corrosion of zinc and Zn-Mg alloys with varying microstructures and magnesium contents, Journal of the Electrochemical Society, 161, C156-C161.

Le Bozec, N., Thierry, D., Rohwerder, M., Persson, D., Luckeneder, G., \& Luwem, L., (2013). Effect of carbon dioxide on the atmospheric corrosion of Zn$\mathrm{Mg}-\mathrm{Al}$ coated steel, Corrosion Science, 74, 379-386.

Li, B., Dong, A., Zhu, G., Chu, S., Qian, H., Hu, C., Sun, B., \& Wang, J., (2012). Investigation of the corrosion behaviors of continuously hot-dip galvanizing Zn-Mg coating, Surface and Coating Technology, 206, 3989-3999.

Persson, D., Thierry, D., LeBozec, N., \& Prosek, T., (2013). In situ infrared reflection spectroscopy studies of the initial atmospheric corrosion of Zn-Al-Mg coated steel, Corrosion Science, 72, 54-63.

Prosek, T., Hagströmb, J., Persson, D., Fuertes, N., Lindberg, F., Chocholaty, O., Taxén, C., Serák, J., \& Thierry, D., (2016). Effect of the microstructure of $\mathrm{Zn}-\mathrm{Al}$ and $\mathrm{Zn}-\mathrm{Al}-\mathrm{Mg}$ model alloys on corrosion stability, Corrosion Science, 110, 71-81.

Prosek, T., Larché, N., Vlot, M., Goodwin, F., \& Thierry, D., (2010). Corrosion performance of Zn-Al-Mg coatings in open and confined zones in conditions simulating automotive applications, Materials and Corrosion, 61, 412-420.

Prosek, T., Nazarov, A., Bexell, U., Thierry, D., \& Serak, J., (2008). Corrosion mechanism of model zinc-magnesium alloys in atmospheric conditions, Corrosion Science, 50, 2216-2231.

Rodriguez, J., Chenoy, L., Roobroeck, A., Godet, S., \& Olivier, M., (2016). Effect of the electrolyte pH on the corrosion mechanisms of Zn-Mg coated steel, Corrosion Science, 108, 47-59.

Salgueiro, M., Allély, C., Ogle, K., \& Volovitch, P., (2015). Corrosion mechanisms of Zn(Mg, Al) coated steel in accelerated tests and natural exposure: 1. The role of electrolyte composition in the nature of corrosion products and relative corrosion rate, Corrosion Science, $90,472-481$.

Salgueiro, M., Allély, C., Ogle, K., \& Volovitch, P., (2015). Corrosion mechanisms of $\mathrm{Zn}(\mathrm{Mg}, \mathrm{Al})$ coated steel: the effect of HCO ${ }_{3}^{-}$and NH4+ ions on the intrinsic reactivity of the coating, Electrochimica Acta, 153, 159-169.

Schuerz, S., Fleischanderl, M., Luckeneder, G. H., Preis, K., Haunschmied, T., Mori, G., \& Kneissl, A. C., (2009). Corrosion behaviour of Zn-Al-Mg coated steel sheet in sodium chloride-containing environment, Corrosion Science, 51, 2355-2363.

Schürz, S., Luckeneder, G. H., Fleischanderl, M., Mack, P., Gsaller, H., Kneissl, A. C., \& Mori, G., (2010). Chemistry of corrosion products on Zn-Al-Mg alloy coated steel, Corrosion Science 52, 3271-3279.

Thébault, F., Vuillemin, B., Oltra, R., Allely, C., Ogle, K., \& Heintz, O., (2015). Influence of magnesium content on the corrosion resistance of the cut-edges of $\mathrm{Zn}-\mathrm{Mg}$-coated steel, Corrosion Science, 97, 100-106.

Vimalanandan, A., Bashir, A., \& Rohwerder, M., (2014). Zn-Mg and Zn-Mg-Al alloys for improved corrosion protection of steel: some new aspects, Materials and Corrosion, 65, 392-400.

Volovitch, P., Allely, C., \& Ogle, K., (2009). Understanding corrosion via corrosion product characterization: I. Case study of the role of Mg alloying in ZnMg coating on steel, Corrosion Science, 51, 1251-1262.

Yao, C., Lv, H., Zhu, T., Zheng, W., Yuan, X., \& Gao, W., (2016). Effect of Mg content on microstructure and corrosion behavior of hot dipped Zn-Al-Mg coatings, Journal of Alloys and Compounds, 670, 239-248.

Yoo, J. D., Ogle, K., \& Volovitch P., (2014). The effect of synthetic zinc corrosion products on corrosion of electrogalvanized steel. II. Zinc reactivity and galvanic coupling zinc/steel in presence of zinc corrosion products, Corrosion Science, 83, 32-37.

Zander, D., Pieper, C., \& Köster, U. (2007). Influence of the casting method on microstructure and corrosion of AZ91 and AM50, in: K.U. Kainer (Ed.), Proceedings of the 7th International Conference on Magnesium Alloys and Their Applications, Wiley-VCH Verlag, Weinheim, 757-762. 